\title{
Effects of feeding different levels of dietary fiber through the addition of corn stover on nutrient utilization of dairy heifers precision-fed high and low concentrate diets ${ }^{1}$
}

\author{
G. J. Lascano and A. J. Heinrichs ${ }^{2}$ \\ Department of Dairy and Animal Science, The Pennsylvania State University, University Park 16802
}

\begin{abstract}
The objective of this experiment was to assess the effects of manipulating dietary fiber by replacing corn silage (CS) with lower quality forage as corn stover (CST) when used in high concentrate (HC) and low concentrate (LC) diets for precision-fed dairy heifers. Eight Holstein heifers (335.6 $\pm 7.41 \mathrm{~kg}$ of body weight) were randomly assigned to 2 levels of concentrate: $\mathrm{HC}$ (20\% forage) and LC ( $80 \%$ forage), and to a forage type sequence [0\% of forage as corn stover (CST), $100 \%$ corn silage (CS); $20 \%$ CST, $80 \%$ CS; $40 \%$ CST, $60 \%$ CS; and 60\% CST, 40\% CS] within concentrate level administered according to a split-plot, $4 \times 4$ Latin square design (21-d periods). Heifers fed HC had higher apparent total-tract dry matter digestibility (DMD). Increasing the fiber level by increasing the amount of CST in the diet resulted in a linear decrease of DMD and organic matter digestibility. Heifers fed LC diets had higher neutral detergent fiber (NDF) digestibility and tended to have lower acid detergent fiber (ADF) digestibility than those fed $\mathrm{HC}$ diets. Substituting CS with 20\% CST resulted in the highest NDF and ADF digestibilities. Digestibility of $\mathrm{N}$ was not different, but $\mathrm{N}$ retention increased for $\mathrm{HC}$ and decreased quadratically for LC diets. Heifers fed HC diets decreased fecal output, and CST linearly increased these parameters. Urine volume tended to be higher for HC-fed heifers, and increasing dietary fiber through CST inclusion tended to decrease urine output. This shift in water excretion resulted in similar total manure output. Total purine derivative excretion did not differ between treatments, but interacted with CST addition, resulting in a linear increase in microbial protein flow to the duodenum in HC-fed heifers and in a linear decrease in LC diets as CST increased. In conclusion, increasing dietary fiber

Received September 15, 2010

Accepted February 28, 2011.

${ }^{1}$ This research is a component of NC-1042: Management Systems to Improve the Economic and Environmental Sustainability of Dairy Enterprises.

${ }^{2}$ Corresponding author: ajh@psu.edu
\end{abstract}

through CST decreased DMD and organic matter digestibility linearly, whereas NDF and ADF digestibility were maximized when $20 \%$ CST was added to $\mathrm{HC}$ and LC diets. Microbial protein synthesis increased and decreased linearly with CST addition in $\mathrm{HC}$ and LC diets, respectively. Retention of $\mathrm{N}$ increased and decreased quadratically with CST addition in HC and LC diets, respectively. Total manure excretion was not different between $\mathrm{HC}$ or LC diets.

Key words: fiber, precision-feeding, dairy heifer

\section{INTRODUCTION}

Controlling DMI increases nutrient efficiency mainly because metabolic nutrient costs are lower when nutrient amounts are precisely supplemented in heifer diets. The tissues responsible for digestion, absorption, and intermediary metabolism must support intense oxidative metabolism, which determines the availability of nutrients remaining for maintenance, growth, and productive functions (Huntington and Reynolds, 1983). Thus, reduced diet nutrient intake has attracted growing attention to improve feed utilization by ruminants. Modifying the forage to concentrate ratio $(\mathbf{F}: \mathbf{C})$ results in high (HC) and low concentrate (LC) diets that allow precision-fed dairy heifers to achieve similar nutrient intakes under these scenarios.

Recently, the use of $\mathrm{HC}$ compared with LC diets fed restrictively has shown similar effects on rumen fermentation (Lascano et al., 2009a; Lascano and Heinrichs, 2009), improved digestibility of nitrogen and organic matter (Zanton and Heinrichs, 2009), showed no difference in ammonia emissions to the environment (Lascano et al., 2008), reduced manure output (Moody et al., 2007), and resulted in similar milk yields when fed during the different phases of the rearing period (Zanton and Heinrichs, 2010). Noteworthy is that inclusion of roughages such as corn stover (CST) might be beneficial to increase effective fiber and reduce readily available carbohydrates in $\mathrm{HC}$ diets (Zebeli et al., 2006). However, when CST (low quality forage) is added to LC high forage diets (a common practice 
used to feed heifers; Heinrichs et al., 1987) that provide enough effective fiber, detrimental effects on nutrient utilization and digestibility might make its use not beneficial. Effective fiber sources such as CST added to rations in low amounts help the formation of a healthy rumen mat (Eastridge et al., 2009). In growing dairy heifers, digesta passage rates are higher due to a lower rumen capacity (Van Soest, 1994), and addition of CST may modulate passage and utilization of nutrients in the rumen.

The level of fiber or NDF in dairy heifer diets is important in maintaining proper rumen function. When evaluating the effects of precision feeding in dairy heifers, studies have fed diets from 19 to 40\% NDF (Moody et al., 2007; Zanton and Heinrichs, 2008; Lascano et al., 2009b). However, the relative importance of fiber to feed efficiency in the heifer has yet to be studied in detail. Therefore, the objective of this experiment was to study the effect of increasing fiber levels through the replacement of corn silage (CS) with CST in dairy heifers by way of monitoring total-tract nutrient utilization when feeding 2 different F:C. The hypothesis was that in heifers with controlled DMI, CST would enhance nutrient utilization in HC-fed heifers and be detrimental in an already high fiber LC diet.

\section{MATERIALS AND METHODS}

\section{Animals and Experimental Design}

All procedures involving animals were approved by the Pennsylvania State University Institutional Animal Care and Use Committee. Eight Holstein heifers $(362.45 \pm 4.53 \mathrm{~d}$ of age and $335.6 \pm 7.41 \mathrm{~kg}$ of BW) were randomly assigned to 2 forage levels: HC (20\% forage) and LC ( $80 \%$ forage) and to a forage type sequence (0\% of forage as CST, $100 \%$ CS; $20 \%$ CST, $80 \%$ CS; $40 \%$ CST, 60\% CS; $60 \%$ CST, $40 \%$ CS) within forage level. Heifers were assigned to a split-plot, $4 \times 4$ Latin square design with 21-d periods. The whole-plot factor was diet F:C and the subplot was proportion of CST in the forage fraction of the diet. All diets were provided as TMR at levels calculated to provide similar intakes of $\mathrm{ME}$ and allow for $800 \mathrm{~g} / \mathrm{d}$ of ADG. Intake of $\mathrm{CP}$, minerals, and vitamins was constant across all diets, but NDF and NFC varied with the ingredients composing the treatment rations (Table 1). Heifer BW were measured and averaged on $\mathrm{d} 0$ and 1 and on $\mathrm{d} 7$ and 8 of each period to determine the amount of feed offered for the following interval. Rations were mixed daily before feeding at $1200 \mathrm{~h}$ by preparing $\mathrm{HC}$ and LC with 2 different CST to CS ratios and subsequently mixing proportions of these diets to obtain the other 2 CST:CS. Heifers were housed in individual stalls (117 $\times 302 \mathrm{~cm}$ ) in a ventilated, environmentally controlled tie-stall barn with rubber mattress bedding, and were allowed access to an exercise lot for $2 \mathrm{~h}$ before feeding on days on which sampling was not occurring. Water was available ad libitum, and daily consumption was monitored individually using unidirectional flow meters (Sensus Metering Systems, Uniontown, PA).

\section{Sample Collection and Analysis}

Adaptation to treatment rations was made over the first $15 \mathrm{~d}$ of each period; feces and urine were collected from d 15 to 21 (6-d total collection). Heifers were kept for $30 \mathrm{~d}$ (pretrial period) before starting the experiment to adapt to the tie-stall facility and standard diets. Urine was collected via modified urine device (Lascano et al., 2010), weighed, and subsampled daily after feeding. A $250-\mathrm{mL}$ subsample was frozen at $-20^{\circ} \mathrm{C}$ for further analysis. Urine $\mathrm{pH}$ was monitored and acidified to $\mathrm{pH}<2$ by the addition of $12 \mathrm{~N} \mathrm{HCl}$ as required to minimize $\mathrm{NH}_{3}$ volatilization. Feces were collected hourly and stored in airtight containers; every 24 $\mathrm{h}$ total collection of feces was mixed, weighed, recorded, and subsampled. For $2 \mathrm{~d}$ /period, feces and unacidified, chilled $\left(4^{\circ} \mathrm{C}\right)$ urine were subsampled (1 observation/ heifer per period), and $\mathrm{NH}_{3}$ volatilization was analyzed using a bench-top, steady-state (dynamic) flux chamber under laboratory conditions as detailed by Lascano et al. (2008). Feedstuffs, TMR, feces (dry basis) and urine (wet basis) were composited by period. Samples were dried in a $55^{\circ} \mathrm{C}$ forced-air oven for $4 \mathrm{~d}$, ground through a 1-mm screen using a Wiley mill (Arthur H. Thomas, Philadelphia, PA), and analyzed for DM, OM, ash (AOAC, 1990), ADF, sulfuric acid detergent fiber (acid detergent lignin, ADL), and NDF (Van Soest et al., 1991) using an Ankom ${ }^{200}$ Fiber Analyzer (Ankom Technology Corp., Fairport, NY) with heat-treated $\alpha$-amylase and sodium sulfite utilized in the NDF procedure. Starch was analyzed on reground samples $(<0.5$-mm screen) using a modified procedure reported by Zanton and Heinrichs (2009). Dried feed and fecal samples, and thawed urine samples were analyzed for $\mathrm{N}$ using the Kjeldahl method (AOAC, 1990). Urine samples were diluted with distilled water (dilution factor 1:10), and $\mathrm{NaOH}$ was used as a solvent for creatinine (Cat No. 0400-100, Stanbio Laboratory, Boerne, TX), uric acid (Cat No. 1045-225, Stanbio Laboratory), and allantoin (Chen, 1989). Urinary purine derivative (PD; allantoin and uric acid) excretion was used to estimate duodenal microbial N (Chen and Gomes, 1992). Metabolizable energy intake was calculated for each heifer within each period using observed digestible OM intake $\times 4.409 \times 0.82(\mathrm{NRC}, 2001)$. 
Table 1. Ingredient and chemical composition of low (LC) or high (HC) concentrate diets containing 4 levels of corn stover addition $(0,20,40$, or $60 \%$ corn stover in the 20 or $80 \%$ forage fraction of the diet)

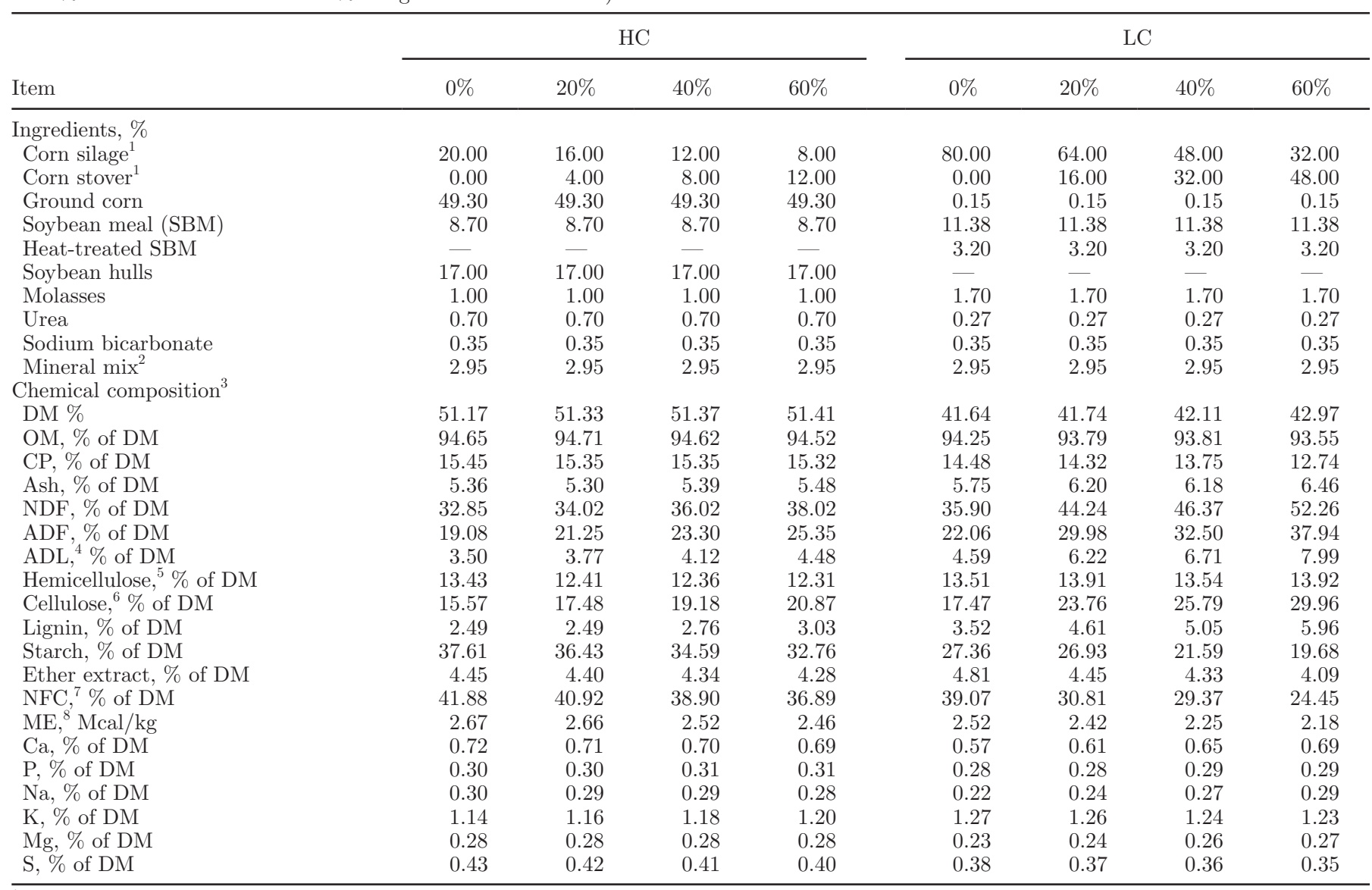

${ }^{1}$ Corn silage contained 36.5\% DM, 33.7\% NDF, $21.9 \%$ ADF, $8.5 \%$ CP, and 32.4\% starch on DM basis. Corn stover contained $88.8 \%$ DM, $85.3 \%$ $\mathrm{NDF}, 58.1 \% \mathrm{ADF}, 4.6 \% \mathrm{CP}$, and $0.6 \%$ starch on DM basis.

${ }^{2}$ Mineral mix contained $7.8 \%$ vitamin E, $2.6 \%$ vitamin ADE, $28.6 \%$ distillers corn with soluble vitamin D, $14.6 \%$ plain salt, $36.5 \%$ limestone, $2.6 \%$ magnesium oxide, $5.7 \%$ trace mineral premix, and $1.6 \%$ selenium premix on DM basis.

${ }^{3} \mathrm{n}=8$ composite samples representing 24 samples per treatment taken daily throughout the collection periods of the experiment. All ingredients and nutrients are expressed on a DM basis unless otherwise specified.

${ }^{4}$ Acid detergent lignin.

${ }^{5}$ Hemicellulose $=$ NDF - ADF .

${ }^{6}$ Cellulose $=\mathrm{ADF}-\mathrm{ADL}$.

${ }^{7}$ Calculated from ingredients as $\mathrm{NFC}=100-(\mathrm{NDF}+\mathrm{CP}+$ ether extract + ash $)$.

${ }^{8}$ Estimated as $\mathrm{ME}=$ total digestible nutrients $\times 0.04409 \times 0.82$.

\section{Statistical Analysis}

Statistical analyses were conducted in SAS software, version 9.2 for Windows (SAS Institute, Cary, NC) using the mixed procedure. All dependent variables were analyzed as a $4 \times 4$ Latin square design. A split-plot design was used with forage level as the whole plot and CST proportion in the forage fraction of the diet as the subplot. Sources of variation associated with fixed design effect of period and fixed treatment effects of forage level, CS:CST, and their interaction were used, with heifer within forage level included as a random effect. The sequences of CS:CST were balanced for car- ryover with respect to previous CS:CST level such that all treatments followed every other treatment once; therefore, fixed effect of previous treatment was also included in statistical analysis. For observations where multiple measures occurred in a period, fixed effect of time and its interaction with other fixed effects was included in the model. Repeated measurements (Littell et al., 1998) including simple, autoregressive one, and compound symmetry covariance structures were utilized in the analysis depending on low values received for goodness of fit measures, Akaike's information criterion, and Schwarz's Bayesian criterion. Forage level effect was assessed with denominator degrees of freedom 
and error term as associated with whole-plot error of heifer within forage, and the effects of CS:CST and the interaction were evaluated against the pooled residual error. Normality of residuals was evaluated using the Shapiro-Wilk test for normality. Differential responses between F:C and CST addition were assessed for some variables through mixed model regression analysis; output from this analysis is displayed as the adjusted (for random effect of heifer) response against CST addition. Least squares means are presented in tables, and evidence for statistical significance was declared at $P<$ 0.05 and trends were indicated at $P<0.10$.

\section{RESULTS AND DISCUSSION}

\section{Nutrient Intakes}

Diet ingredient and chemical composition are presented in Table 1. Diets were planned to differ mainly in provision of forage fiber, and NDF concentrations increased linearly in the diet with CST addition. The CST replaced CS in 20-percentage-unit increments from 0 to $60 \%$ of the forage fraction of the diet. The rest of the components of the rations were similar among treatments. Nutrient intakes are presented in Table 2. Increased intake of fiber components (NDF) demands the reduction of either $\mathrm{CP}$ or starch to attain isonitrogenous and isocaloric conditions. In this case, starch decreased linearly with increasing NDF intake, which resulted in 8 levels of NDF and starch intake. Intake of $\mathrm{N}$ was similar among treatments $\left(1.69 \mathrm{~g} / \mathrm{kg}\right.$ of $\left.\mathrm{BW}^{0.75}\right)$; this value was reported by Zanton and Heinrichs (2009) to optimize $\mathrm{N}$ utilization in precision-fed heifers. Heifers were fed diets that provided 14.72 and $14.62 \mathrm{Mcal} / \mathrm{d}$ for HC and LC, respectively. Daily DMI were increased as CST incorporation increased to provide isocaloric diets, because ME was reduced as CST was incorporated in the diet. Actual ADG was greater than expected during the pretrial period, and intakes of DM and ME were reduced to allow the targeted ADG to be reached. Heifers fed HC had lower DMI (HC 5.68 vs. LC $6.71 \pm$ $0.04 \mathrm{~kg} / \mathrm{d}$ ), and this was similar to other experiments where intake has been controlled with similar F:C diets (Lascano et al., 2009b; Zanton and Heinrichs, 2009). Rate of gain and ME intake $(0.19 \pm 0.05 \mathrm{Mcal} / \mathrm{kg}$ of $\left.\mathrm{BW}^{0.75}\right)$ between the 2 groups were not different $(P=$ $0.23)$.

\section{Diet Digestibility}

Apparent total-tract nutrient digestibilities are presented in Table 3. The lower level of concentrate in the diet decreased total-tract digestibility of DM, OM, NDF, ADF, cellulose, and starch. Apparent DM and
OM digestibilities were similar to results observed by Lascano et al. (2009b) when heifers were fed diets composed solely of 40 or $80 \% \mathrm{CS}$. Other researchers have reported increased DM, OM, NDF, ADF, and starch apparent digestibilities when $\mathrm{HC}$ or LC diets have been offered restrictively (Colucci et al., 1989; Reynolds et al., 1991; Murphy et al., 1994).

Digestibility of NDF and ADF followed a similar pattern as DM and OM apparent digestibility. Zanton and Heinrichs (2009) observed that NDF digestibility followed the same pattern as OM digestibility when dairy heifers were fed either $\mathrm{HC}$ or LC (75 or $25 \%$ concentrate) and concluded that reduction of NDF digestibility was mainly due to decreased hemicellulose digestibility because ADF digestibility was not different between concentrate levels. However, in the present experiment, hemicellulose digestibility was similar between concentrate levels, and the effect observed in NDF and ADF digestibility was caused by a reduction in cellulose digestibility in the LC diet. The difference between the 2 experiments is that the earlier study manipulated N levels (Zanton and Heinrichs, 2009) and the forage component comprised a combination of CS and wheat straw, whereas the present experiment manipulated the fiber fraction within different $\mathrm{F}: \mathrm{C}$ diets through increasing CST, which has high cellulose concentrations. In a control-feeding scenario, the passage rate of the whole digesta was reduced (Colucci et al., 1990), allowing more time for hemicellulose to be digested evenly between concentrate levels as in the present experiment, and allowing cellulose to have a higher retention time and be further enhanced in the $\mathrm{HC}$ diets. However, these results could be masked because in the $\mathrm{HC}$ diet, soybean hulls that have a high NDF digestion rate (Hall et al., 1998), mainly higher hemicellulose (NDF-ADF) digestibility (Sarwar et al., 1991), represented $17 \%$ of the diet. Starch digestibility seems to be increased by higher retention time of $\mathrm{HC}$ diets (Lascano and Heinrichs, 2009) as well as by a more numerous amylolytic bacteria population associated with this type of diet (Brown et al., 2006). These results are in agreement with results observed in limitfed sheep or cattle (Colucci et al., 1989; Murphy et al., 1994).

Apparent DM, OM, cellulose, starch, and ash digestibilities were reduced linearly as CST increased from 0 to $60 \%$ in the forage fraction of diets. In part, this can be explained because increased DMI has been associated with lower DM and OM digestibilities when heifers have been precision-fed (Zanton and Heinrichs, 2008). In this experiment, a higher proportion of CST in the diets resulted in higher DMI to attain the targeted ME. It is also important to note the inverse relationship between NDF levels in the ration and DM 
Table 2. Feed intake of dairy heifers fed differing forage to concentrate ratios (F:C) as low (LC) or high (HC) concentrate diets containing 4 levels of corn stover addition $(0,20,40$, or $60 \%$ corn stover in the 20 or $80 \%$ forage fraction of the diet)

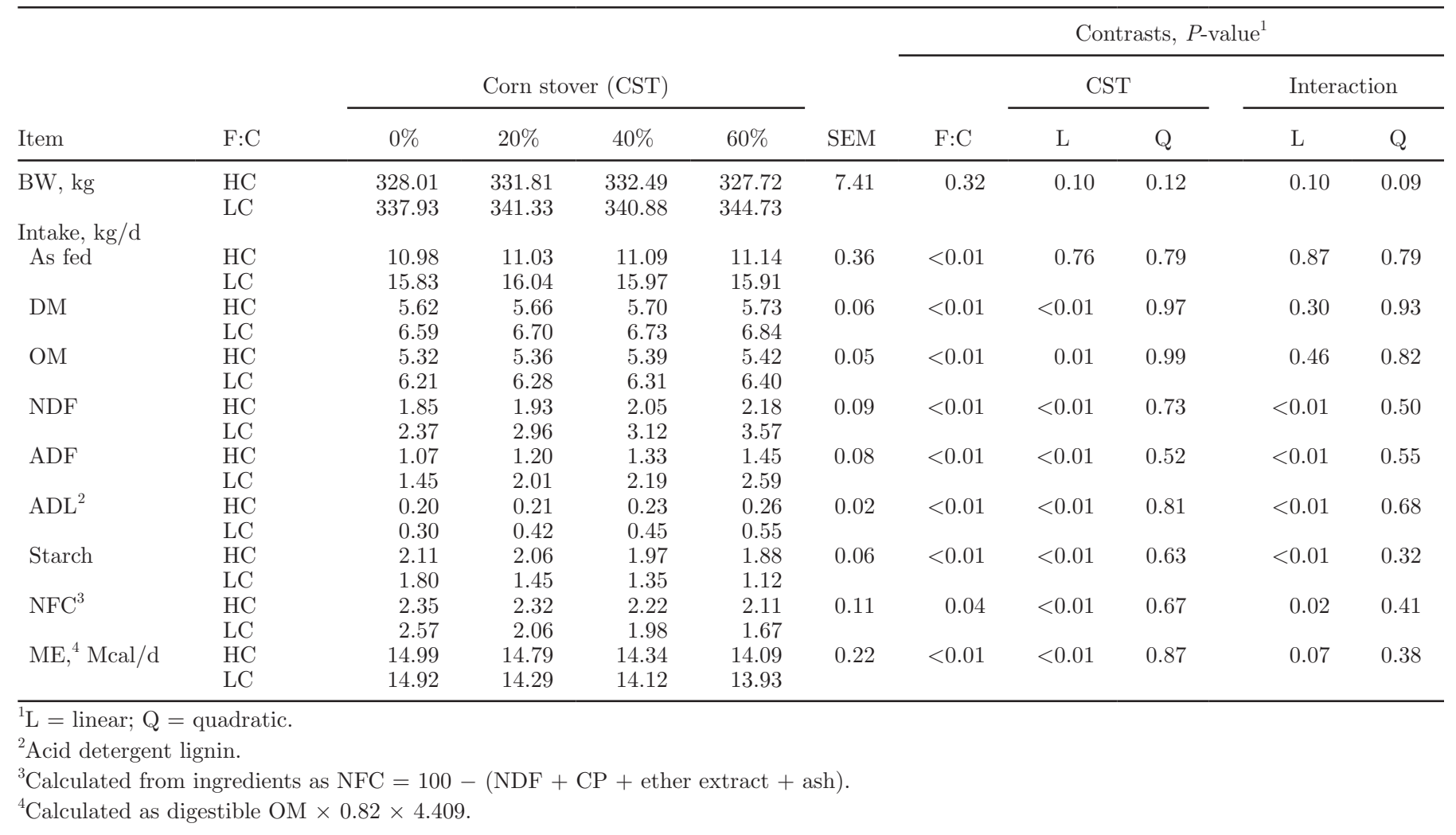

and OM digestibility (Van Soest, 1994). Increasing levels of CST resulted in increased levels of NDF that modulate the response in OM digestibility (Firkins et al., 2001). In an effort to characterize this response, a mixed regression analysis was modeled and showed that CST inclusion in the forage fraction modulated OM digestibility linearly with different intercepts and slopes for $\mathrm{HC}$ and $\mathrm{LC}$ diets (Figure 1). Thus, OM digestibility was different between $\mathrm{F}: \mathrm{C}$ diets, and increased dietary $\mathrm{NDF}$ concentration caused a greater reduction in OM digestibility in LC diets. It has been observed that OM and DM digestibility were reduced when low quality wheat straw (similar in composition to CST) replaced concentrates in mid-lactation cow diets (Halevi et al., 1973). In the cited experiment, NDF digestibility was reduced by straw inclusion, but F:C increased as straw was included in the diet. Replacing CS with CST within the same $\mathrm{F}$ : $\mathrm{C}$ results in similar hemicellulose concentration in the diet, but cellulose and lignin (ADF) are increased and reduce $\mathrm{OM}$ and $\mathrm{DM}$ digestibility due to lower digestibility of cellulose (Table 3; Keys and Smith, 1981).

Starch digestibility was reduced with increasing dietary NDF concentration through the addition of CST. It has been shown that starch digestibility in lactating cows decreased $0.6 \%$ for every $1 \%$ increase in dietary NDF concentration (Firkins et al., 2001). Results from the present experiment are in close agreement with this observation. Starch digestibility has been depressed by increasing fiber through addition of alfalfa hay (from 90 to $440 \mathrm{~g} / \mathrm{kg}$ ) in the diet of steers (Nordin and Campling, 1976). It seems that NDF concentration in the diet increases digesta passage rates of grain and that intestinal digestion of starch may be limited (Galyean and Defoor, 2003). Thus, it can be suggested that passage of ruminally unfermented starch was accelerated as CST was incorporated in the diet, reducing its totaltract digestibility. Similar results were reported when dietary roughage and NDF levels were increased in corn-based diets (Cole et al., 1976; Wylie et al., 1990).

Apparent $\mathrm{N}$ digestibility was not different between $\mathrm{F}: \mathrm{C}$ treatments or with increasing levels of CST in diets, similar to previous studies (Moody et al., 2007; Lascano et al., 2009b). Urine $\mathrm{N}$ and $\mathrm{N}$ retention were not different among $\mathrm{F}$ : $\mathrm{C}$ treatments, but additional increments of CST interacted quadratically with level of concentrate in the diet (Table 3). A quadratic decrease in $\mathrm{N}$ excreted in urine in the $\mathrm{HC}$ diet was noted, whereas the opposite was observed in the LC diet as CST increased proportionally in diets. This effect resulted 
Table 3. Nutrient digestibility in dairy heifers fed differing forage to concentrate ratios (F:C) as low (LC) or high (HC) concentrate diets containing 4 levels of corn stover addition $(0,20,40$, or $60 \%$ corn stover in the 20 or $80 \%$ forage fraction of the diet)

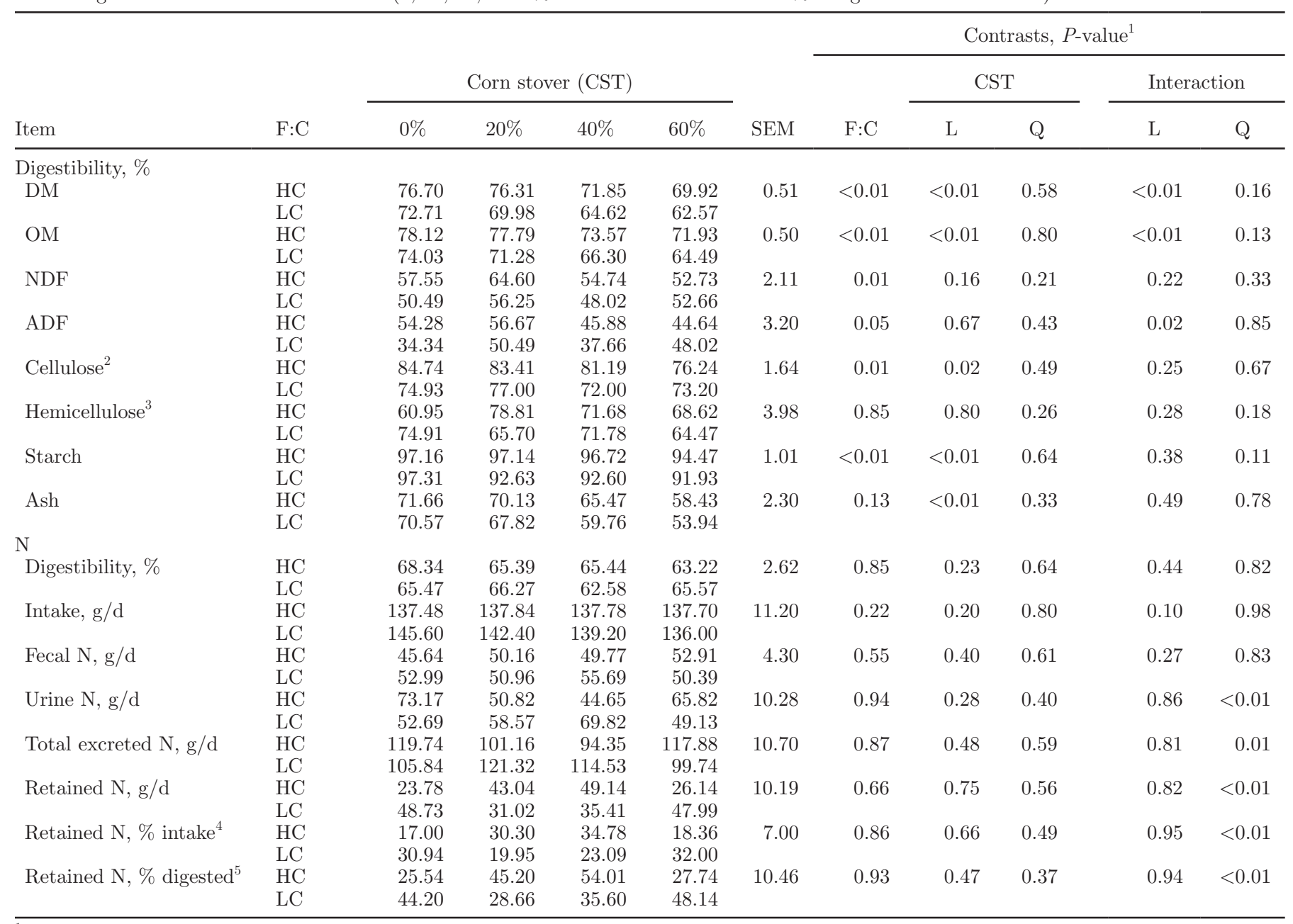

${ }^{1} \mathrm{~L}=$ linear; $\mathrm{Q}=$ quadratic.

${ }^{2}$ Cellulose $=\mathrm{ADF}-\mathrm{ADL} . \mathrm{ADL}=$ acid detergent lignin.

${ }^{3}$ Hemicellulose $=$ NDF - ADF.

${ }^{4}$ Retained $\mathrm{N}, \%$ intake $=$ percentage of $\mathrm{N}$ intake and grams of $\mathrm{N}$ retained.

${ }^{5}$ Retained $\mathrm{N}, \%$ digested $=$ percentage of $\mathrm{N}$ digested and grams of $\mathrm{N}$ retained.

in a reverse quadratic response for $\mathrm{N}$ retention. Beckman and Weiss (2005) observed a linear increase in N retention as the NDF:starch ratio was manipulated by including soyhulls and cottonseed hulls to replace corn grain, obtaining dietary NDF concentrations of 25, 29, and $32 \%$ in lactating cows. It seems that $\mathrm{N}$ utilization increased in $\mathrm{HC}$ diets as dietary fiber provided an improved rumen environment and $\mathrm{pH}$, but $\mathrm{N}$ utilization was reduced as energy became limiting. The quadratic reduction observed in $\mathrm{LC}$ diets was elicited after diet NDF concentration went from 36 to $44 \%$, but was recovered at $52 \%$ NDF. In a controlled-feeding scenario, rate of passage is increased as DMI is higher, which was the case as CST increased in these diets. Limiting intake of $\mathrm{HC}$ diets in particular reduces passage rates of materials from the rumen (Eng et al., 1964; Colucci et al., 1990). As a result, rumen bacterial and feed $\mathrm{N}$ flows to the small intestine are reduced (Murphy et al., 1994). An uncoupling of carbohydrates and degradable protein could have reduced $\mathrm{N}$ retention for intermediate levels of dietary fiber in LC-fed heifers, but at the highest level (60\% CST) more RUP was available for absorption at the small intestine because of an increased rate of passage of digesta (NRC, 2001). However, the feasibility of undertaking this strategy to increase RUP is limited by the reduction in OM digestibility. Whereas $\mathrm{HC}$ diets reduce passage rate of digesta, protein sources with lower rumen degradability rates can increase $\mathrm{N}$ efficiency within the animal. Further research is needed in this respect. 


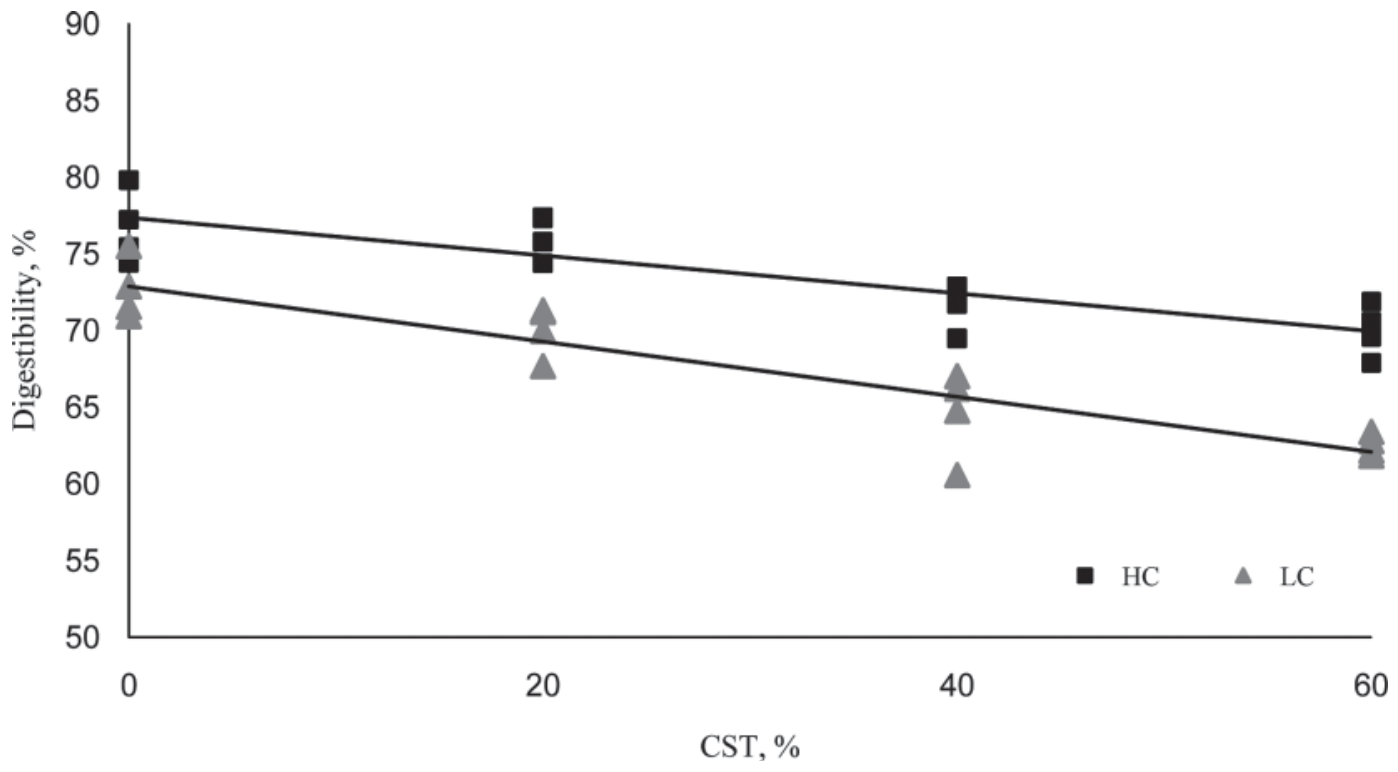

Figure 1. Effect of increasing corn stover (CST) level on OM digestibility (y-axis) in rations of dairy heifers fed differing forage to concentrate ratios $(\mathrm{F}: \mathrm{C})$ as low $(\mathrm{LC} ; \boldsymbol{\Delta})$ or high $(\mathrm{HC} ; \mathbf{\square})$ concentrate diets containing 4 levels of CST addition (x-axis; 0, 20, 40, and $60 \%$ of CST in the 20 or $80 \%$ forage fraction of the diet). Lines and individual coefficients are significantly different $(P<0.05)$. Parenthetical values associated with the equation are standard errors. Individual equations are HC: $\mathrm{y}=79.07( \pm 0.71 ; P \leq 0.01)-0.106( \pm 0.04 ; P=0.01) \mathrm{x}$, and LC: $\mathrm{y}=74.31$ $( \pm 0.64 ; P \leq 0.01)-0.20( \pm 0.04 ; P \leq 0.01) \mathrm{x}$.

\section{Nutrient Excretion}

Environmental excretion data are presented in Table 4. Wet fecal, dry fecal, and fecal water outputs were lower for $\mathrm{HC}$ compared with $\mathrm{LC}$ diets. This is in agreement with previous results when dairy heifers have been precision-fed different F:C diets (Moody et al., 2007; Lascano et al., 2009b; Zanton and Heinrichs, 2009). Wet fecal output increases proportionally as $\mathrm{F}: \mathrm{C}$ increases. The percentage of wet feces observed in the experiments cited above and in the present experiment were $54,60,64$, and $69 \%$ of what was excreted by LC-fed heifers when F:C was 20:80 (this experiment), 25:75 (Zanton and Heinrichs, 2009), 33:67 (Moody et al., 2007), and 40:60 (Lascano et al., 2009b). Decreased output is consistent with the enhanced DM and OM digestibility observed in this experiment. On the other hand, urine output was increased in HC-fed heifers; other experiments have failed to observe differences in urine output among $\mathrm{HC}$ or LC diets, but these experiments fed lower levels of concentrate (67 and 60\% respectively; Moody et al., 2007; Lascano et al., 2009b). However, when higher proportions of concentrate were fed to dairy heifers [75 and $80 \%$ in Zanton and Heinrichs (2009) and the present experiment, respectively], significant differences in urine output were observed. It has been suggested that increased water consumption from limit-fed heifers results in higher urine excretion (Hill et al., 2007), but Zanton and Heinrichs (2008) fed lower DMI than Hill et al. (2007) with no differences in urine output, refuting this explanation.

When comparing $\mathrm{HC}$ to $\mathrm{LC}$ diets, one of the main dietary differences is the proportion of fiber included in the diet. It has been suggested that water-holding capacity of undigested fiber plays an important role in determining urine output (Zanton and Heinrichs, 2009). Total manure excretion was not different because of the inverse relationship between fecal water and urine output. Despite greater wet fecal output for LC-fed heifers, lower urine output balanced total manure output compared with HC-fed heifers, in which the opposite effect was observed. A shift was observed toward more water excreted as urine in $\mathrm{HC}$ diets compared with more water excreted in feces for LC diets.

A linear increase was observed in wet and dry fecal output as well as fecal water as CST increased in the rations. These results are consistent with the linear reduction observed in DM and OM digestibility and reflect the lower digestibility of CST. Urine output decreased linearly and followed the same trend when HC was compared with LC. From these results, it is clear that dietary NDF concentrations are modulating water balance in the animal. Other experiments have attributed water excretion to minerals such as $\mathrm{P}$ and $\mathrm{K}$ (Bannink et al., 1999; Burkholder et al., 2004), but it has to be taken into consideration that in the present experiment concentration of these minerals was similar among treatments (Table 1). As reported previously 
Table 4. Excretion parameters of dairy heifers fed differing forage to concentrate ratios (F:C) as low (LC) or high (HC) concentrate diets containing 4 levels of corn stover addition $(0,20,40$, or $60 \%$ corn stover in the 20 or $80 \%$ forage fraction of the diet)

\begin{tabular}{|c|c|c|c|c|c|c|c|c|c|c|c|}
\hline \multirow{2}{*}{ Item } & \multirow{2}{*}{$\mathrm{F}: \mathrm{C}$} & & & & & & \multicolumn{5}{|c|}{ Contrasts, $P$-value ${ }^{1}$} \\
\hline & & \multicolumn{4}{|c|}{ Corn stover (CST) } & SEM & $\mathrm{F}: \mathrm{C}$ & \multicolumn{2}{|c|}{ CST } & \multicolumn{2}{|c|}{ Interaction } \\
\hline \multirow[t]{2}{*}{ Wet feces, $\mathrm{kg} / \mathrm{d}$} & $\mathrm{HC}$ & 6.69 & 6.93 & 7.95 & 8.25 & 0.38 & $<0.01$ & $<0.01$ & 0.05 & $<0.01$ & 0.04 \\
\hline & LC & 11.21 & 13.88 & 14.76 & 15.66 & & & & & & \\
\hline Dry feces, $\mathrm{kg} / \mathrm{d}$ & $\mathrm{HC}$ & 1.32 & 1.34 & 1.60 & 1.72 & 0.04 & $<0.01$ & $<0.01$ & 0.43 & $<0.01$ & 0.12 \\
\hline Fecal water, ${ }^{2} \mathrm{~kg} / \mathrm{d}$ & $\mathrm{LC}$ & 9.34 & 11.79 & 12.30 & 13.02 & & & & & & \\
\hline \multirow{2}{*}{ Urine, $\mathrm{kg} / \mathrm{d}$} & $\mathrm{HC}$ & 17.03 & 15.64 & 15.47 & 13.34 & 2.65 & 0.08 & 0.02 & 0.86 & 0.99 & 0.53 \\
\hline & LC & 10.47 & 9.29 & 7.22 & 7.38 & & & & & & \\
\hline \multirow[t]{2}{*}{ Manure, $\mathrm{kg} / \mathrm{d}$} & $\mathrm{HC}$ & 22.45 & 23.81 & 23.46 & 22.55 & 2.52 & 0.65 & 0.66 & 0.29 & 0.65 & 0.66 \\
\hline & $\mathrm{LC}$ & 20.54 & 22.23 & 21.18 & 21.91 & & & & & & \\
\hline \multirow{2}{*}{ Total water excreted, $\mathrm{kg} / \mathrm{d}$} & $\mathrm{HC}$ & 21.13 & 22.47 & 21.86 & 20.82 & 2.53 & 0.52 & 0.87 & 0.28 & 0.78 & 0.63 \\
\hline & $\mathrm{LC}$ & 18.74 & 20.22 & 18.80 & 19.35 & & & & & & \\
\hline $\mathrm{g} / \mathrm{d}$ & LC & 18.54 & 24.50 & 22.93 & 25.16 & & & & & & \\
\hline
\end{tabular}

${ }^{1} \mathrm{~L}=$ linear; $\mathrm{Q}=$ quadratic.

${ }^{2}$ Weight lost on drying at $55^{\circ} \mathrm{C}$.

(Moody et al., 2007; Lascano et al., 2009b; Zanton and Heinrichs, 2009) when comparing F:C treatments, no difference was observed at the total manure excretion level, but water being excreted in urine was shifted toward fecal water for the HC-fed heifers (Figure 2).

Emissions of $\mathrm{NH}_{3}-\mathrm{N}$ from daily manure are presented in Table 4. Emissions from slurries of manure from heifers fed $\mathrm{HC}$ resulted in greater rates per unit of manure, but not on a daily basis. This is in agreement with the results of Lascano et al. (2008), who used the same procedure and observed no difference in dairy heifers control-fed HC or LC diets. Dietary manipulation has affected $\mathrm{NH}_{3}$ emissions (James et al., 1999; Misselbrook et al., 2005), but manipulation of $\mathrm{F}: \mathrm{C}$ has resulted in no differences. Zanton and Heinrichs (2009) observed that $\mathrm{NH}_{3}$ volatilization and proportion of urinary urea

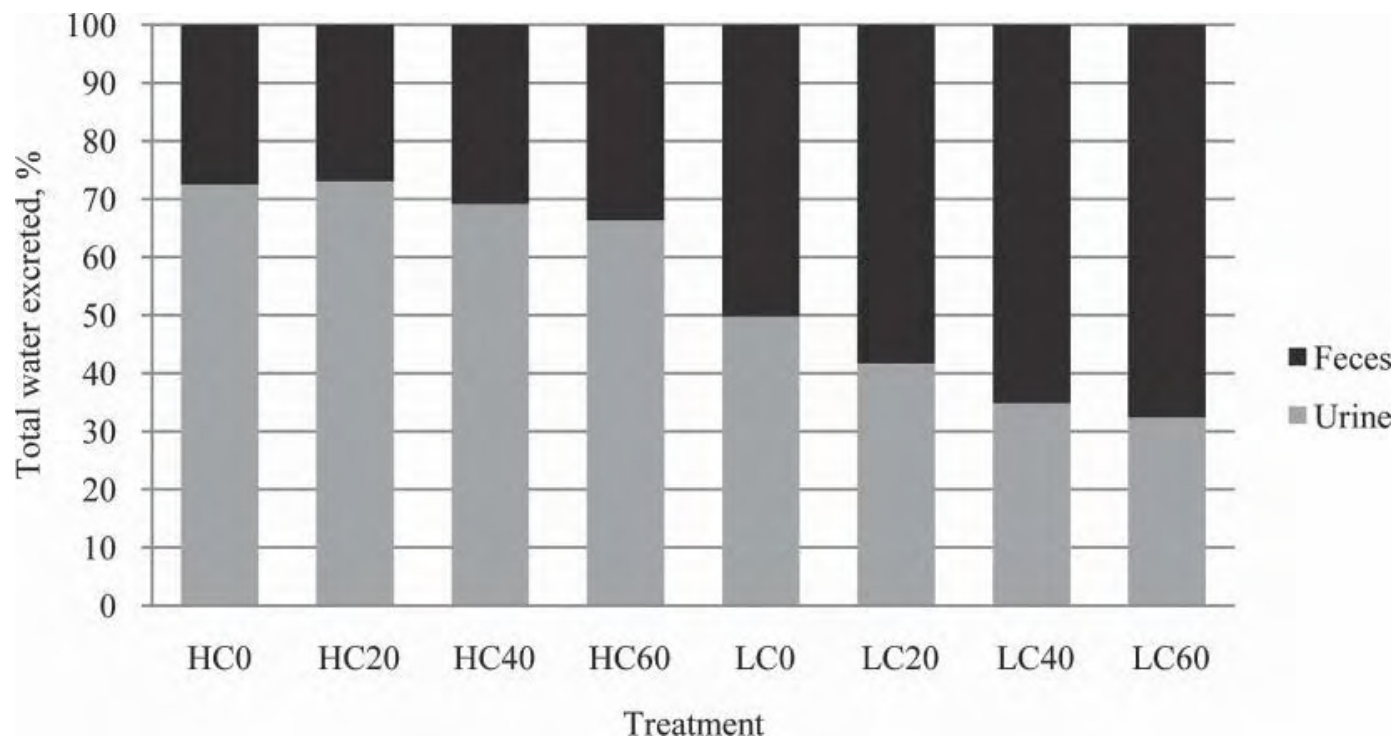

Figure 2. Effect of increasing the corn stover (CST) level in rations of dairy heifers fed differing forage to concentrate ratios (F:C) as low (LC) or high (HC) concentrate diets at 4 levels of CST addition as forage (0,20,40, and 60\% CST in the 20 or $80 \%$ forage fraction of the diet) as a percentage of total water excreted in urine and feces (linear CST effect $P<0.01$; SE \pm 2.34 ). 
Table 5. Water intake and proportion excreted of dairy heifers fed differing forage to concentrate ratios (F:C) as low (LC) or high (HC) concentrate diets containing 4 levels of corn stover addition $(0,20,40$, or $60 \%$ corn stover in the 20 or $80 \%$ forage fraction of the diet)

\begin{tabular}{|c|c|c|c|c|c|c|c|c|c|c|c|}
\hline \multirow{2}{*}{ Item } & \multirow{2}{*}{$\mathrm{F}: \mathrm{C}$} & & & & & & \multicolumn{5}{|c|}{ Contrasts, $P$-value ${ }^{1}$} \\
\hline & & \multicolumn{4}{|c|}{ Corn stover (CST) } & SEM & $\mathrm{F}: \mathrm{C}$ & \multicolumn{2}{|c|}{$\mathrm{CST}$} & \multicolumn{2}{|c|}{ Interaction } \\
\hline \multicolumn{12}{|l|}{ Water intake, $\mathrm{L} / \mathrm{d}$} \\
\hline \multirow[t]{2}{*}{ Voluntary } & $\mathrm{HC}$ & 18.28 & 20.73 & 20.42 & 22.90 & 3.39 & 0.21 & 0.56 & 0.55 & 0.14 & 0.55 \\
\hline & $\mathrm{LC}$ & 14.11 & 17.83 & 13.23 & 13.62 & & & & & & \\
\hline \multirow[t]{2}{*}{ Total/kg of DMI } & $\mathrm{HC}$ & 4.22 & 4.63 & 4.53 & 4.97 & 0.60 & 0.24 & 0.59 & 0.64 & 0.18 & 0.60 \\
\hline & LC & 3.54 & 4.08 & 3.40 & 3.45 & & & & & & \\
\hline \multirow[t]{2}{*}{ Total $/ \mathrm{kg}$ of $\mathrm{NDF}$} & $\mathrm{HC}$ & 12.93 & 13.77 & 12.60 & 13.08 & 1.67 & 0.06 & 0.07 & 0.88 & 0.10 & 0.92 \\
\hline & $\mathrm{LC}$ & 9.87 & 9.26 & 7.33 & 6.64 & & & & & & \\
\hline \multicolumn{12}{|l|}{ Water excreted per consumed, ${ }^{3} \%$} \\
\hline \multirow[t]{2}{*}{ Feces } & $\mathrm{HC}$ & 24.92 & 24.36 & 25.94 & 26.34 & 3.34 & $<0.01$ & $<0.01$ & 0.72 & $<0.01$ & 0.45 \\
\hline & LC & 41.19 & 45.68 & 53.79 & 55.64 & & & & & & \\
\hline
\end{tabular}

${ }^{1} \mathrm{~L}=$ linear; $\mathrm{Q}=$ quadratic.

${ }^{2}$ Total water intake $=$ voluntary water intake + feed water.

${ }^{3}$ Consumption is total water intake and excretion includes fecal water calculated as weight lost on drying at $55^{\circ} \mathrm{C}$ and total weight of urine output.

$\mathrm{N}$ volatilized did not differ between $\mathrm{HC}$ or LC diets. A quadratic interaction was observed between $\mathrm{F}$ : C and CST addition in the diets, opposite to the quadratic effect observed for $\mathrm{N}$ retention. Urea excreted in urine is hydrolyzed by urease from feces (Misselbrook et al. 2005), which suggests that as CST increased in the HC diet, a quadratic decrease occurred in urea being excreted in urine and the opposite in LC diets, explaining in part the effect observed for $\mathrm{N}$ retention.

\section{Water Intake}

Water intake and dynamics are presented in Table 5 . Water intake was numerically greater for $\mathrm{HC}$-fed heifers (20.58 vs. $14.7 \mathrm{~kg} / \mathrm{d}$ ), but total water intake (voluntary + feed water) was not different among the F:C groups. Feed water consumption was lower for the HC diet (5.69 vs. $9.23 \mathrm{~kg} / \mathrm{d}$ ) because its DM was lower. This indicates how well regulated water intake is within animals of the same age fed different $\mathrm{F}: \mathrm{C}$ and $\mathrm{DM}$ percentages under similar environmental conditions. Similar water intakes were reported by Zanton and Heinrichs (2009) with precision-fed dairy heifers fed HC or LC diets with increasing level of $\mathrm{N}$. Total water consumed per kilogram of DMI did not differ but more total water per kilogram of NDF intake tended $(P=0.06)$ to be consumed by $\mathrm{HC}$-fed heifers. The percentage of fecal water relative to total water consumed was lower for HC diets (25.39 vs. $45.08 \%)$ and the opposite was observed for urine (60.43 vs. $32.21 \%$ ), but total percentage of water excreted was similar between F:C groups and represented approximately $84 \%$. Thus, the sensible (sweat, saliva, panting) and insensible (respiratory and sweat diffusion) water losses were $16 \%$, which is 9 percentage units lower than what was reported with dairy heifers of greater age and BW (13.4 $\pm 0.3 \mathrm{mo}$ and $362 \pm 8 \mathrm{~kg}$; Zanton and Heinrichs, 2009) housed under similar conditions. It has been reported that as the animal grows, the surface to volume ratio increases; thus, more extensive exposure to the environment through its greater surface results in an increase in water loss (Schmidt-Nielson, 1984).

The shift from urine water toward more fecal water being excreted as CST increased in the diet is noteworthy (Figure 2). Dietary fiber has been suggested to increase water-holding capacity in humans, which increases fecal water content (Burkitt, 1973) and largely affects its passage through the large intestine. Therefore, more water will be excreted in feces than in urine with higher levels of dietary fiber, but the proportion of total water excreted relative to intake $(84 \%)$ was not affected by CST or NDF levels (Zanton and Heinrichs, 2009).

\section{Microbial Protein}

Microbial $\mathrm{N}$ flow to the duodenum is presented in Table 6. No differences were detected for allantoin, total PD, or microbial CP between F:C treatments. It has 
Table 6. Daily urinary excretion of purine derivatives (PD), estimated bacterial CP flow, and creatinine of dairy heifers fed differing forage to concentrate ratios (F:C) as low (LC) or high (HC) concentrate diets containing 4 levels of corn stover addition $(0,20,40$, or $60 \%$ corn stover in the 20 or $80 \%$ forage fraction of the diet)

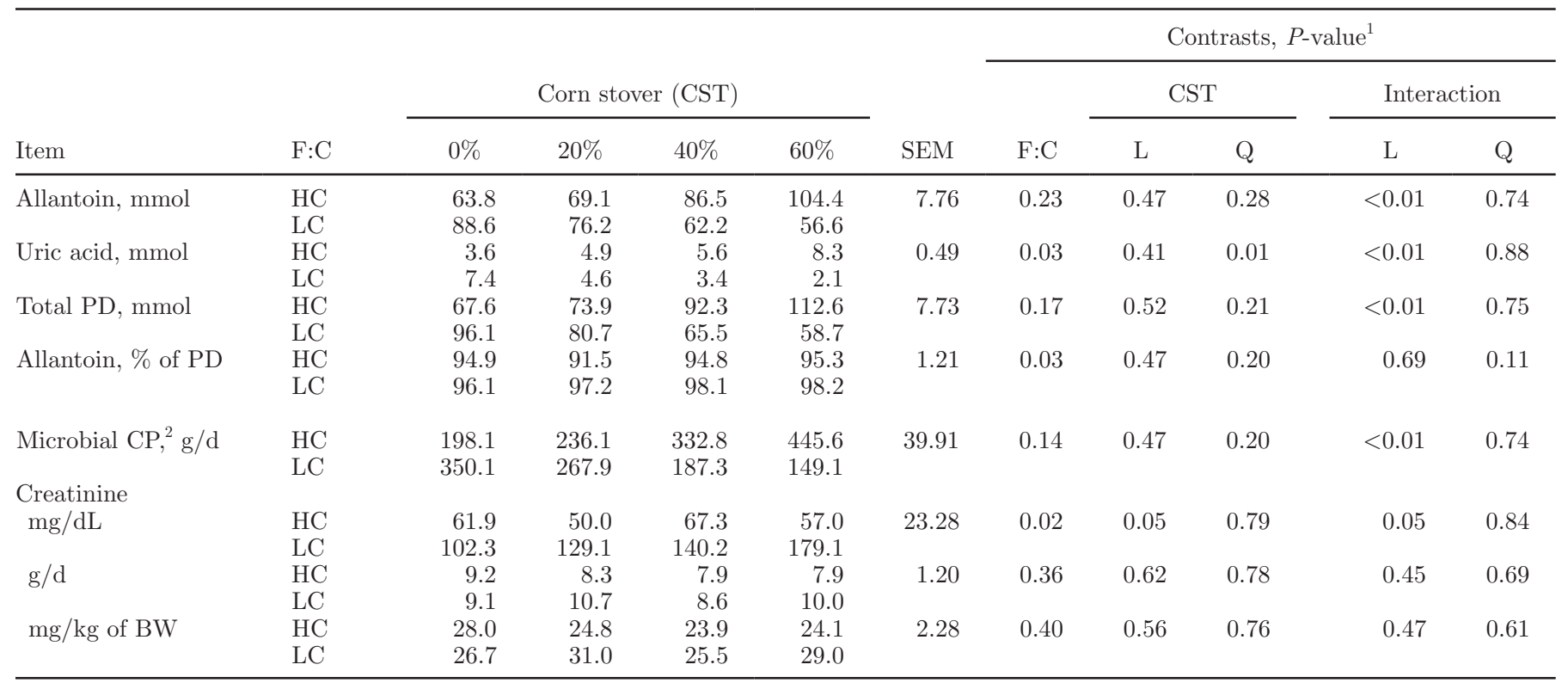

${ }^{1} \mathrm{~L}=$ linear; $\mathrm{Q}=$ quadratic.

${ }^{2}$ Estimated according to the methods and equations of Chen and Gomes (1992).

been suggested that $\mathrm{HC}$ diets decreased the flow of microbial protein to the duodenum because of a decrease in liquid, bacteria, and small particle turnover rates as well as lower ruminal pH (Hungate, 1966; Owens and Isaacson, 1977). In agreement with these observations, Lascano and Heinrichs (2009) reported lower rumen turnover rates as F:C decreased from 80:20 to 40:60 in control-fed heifers ( 88 to $78 \%$, respectively). This is true when comparing the $\mathrm{HC}$ to $\mathrm{LC}$ diet with no CST supplementation (198. 07 vs. $350.07 \mathrm{~g} / \mathrm{d}$ of microbial protein), but because both treatments had incremental CST addition, main effects of $\mathrm{F}$ : $\mathrm{C}$ were not detectable. It has also been reported that decreasing $\mathrm{F}$ : $\mathrm{C}$ increases microbial protein yield (Lascano et al., 2009a; Pina et al., 2009); it is important to note that these experiments increased the concentrate level from 20 to 40 and from 20 to $60 \%$ in the diet, respectively. However, it has been shown that beyond these levels microbial protein decreases with additional concentrate incorporation in the diet. Valadares et al. (1999) reported a quadratic effect in dairy cows fed $20,35,50$, and $65 \%$ concentrate, with the highest microbial protein for the $50 \%$ concentrate diet. They concluded that $35 \%$ NFC is adequate to improve microbial protein synthesis because highly fermentable carbohydrates are more effective than structural carbohydrates to promote microbial growth (Hoover and Stokes, 1991). Stern and Hoover (1979) suggested that NFC levels of 35 to $45 \%$ enhance microbial protein synthesis, and diets fed in the present experiment were all around this range. Reduction in microbial protein synthesis of diets containing levels of concentrate $>70 \%$ is a result of an uncoupled fermentation from rapid degradation of NSC (Polan, 1988), decrease in rumen turnover rate, and detrimental rumen environment conditions (Van Soest, 1994).

Significant linear interaction effects were observed between F:C and CST. In the HC group, where microbial protein should be lower, as mentioned above, incremental CST addition enhanced predicted microbial protein flow to the duodenum and the opposite happened in the LC group. Sources of coarse forage added to HC diets increase rumen turnover rate, besides increasing salivation that provides a ruminal $\mathrm{pH}$ appropriate for a broader range of bacteria types (Hungate, 1966), and thus increased microbial protein synthesis and flow to the duodenum (Owens and Isaacson, 1977). Additionally, addition of CST resulted in minimal but higher DMI that resulted in higher predicted microbial protein flow (Zanton and Heinrichs, 2009). On the other hand, as CST increased in the LC diet, lower predicted microbial protein was observed. This is mainly due to lower availability of readily fermentable carbohydrates. These results are in close agreement with the $35 \%$ dietary NFC proposed by Valadares et al. (1999) to maximize microbial protein synthesis because microbial protein was greatest for the highest and lowest CST inclusion in the $\mathrm{HC}$ and LC diets, which provided either 37 or $39 \%$ NFC, respectively (Table 1). Therefore, CST inclusion 
in $\mathrm{HC}$ diets ( $80 \%$ concentrate) seems to be beneficial to microbial protein synthesis but detrimental in LC diets.

\section{Urine Creatinine}

Urinary creatinine daily excretion was not different among F:C groups. Creatinine concentration $(\mathrm{mg} / \mathrm{dL})$ was lower for $\mathrm{HC}$ diets but was balanced on a daily excretion basis by the higher urine excretion of this group. No differences in daily excretion of creatinine have been reported when heifers have been precisionfed either LC or HC diets (Lascano et al., 2009b; Zanton and Heinrichs, 2009). Zanton and Heinrichs (2009) indicated that total output $(\mathrm{g} / \mathrm{d}$ or $\mathrm{mg} / \mathrm{kg}$ of $\mathrm{BW}$ ) of creatinine suggested a constant muscle mass for heifers fed either $\mathrm{HC}$ or LC diets. An average of $26.8 \mathrm{mg} / \mathrm{kg}$ of BW across heifers fed $\mathrm{HC}$ or LC diets with different levels of CST was observed in this experiment, which is quite similar to the one reported by the latter group of researchers $(24.2 \mathrm{mg} / \mathrm{kg}$ of BW). This indicates that measurement of creatinine has potential for predictive purposes of urine output in dairy heifers as was reported for dairy cows (Valadares et al., 1999).

\section{CONCLUSIONS}

Responses from this experiment support the hypothesis that moderate levels of CST may be beneficial in HC-fed heifers. Digestibility of OM was higher for HCfed heifers because more highly digestible ingredients were part of this diet. Increasing dietary fiber through inclusion of CST decreased DM and OM digestibility linearly while NDF and ADF digestibility were maximized quadratically when intermediate levels of CST were added to $\mathrm{HC}$ or LC diets. Replacing CS with CST resulted in similar hemicellulose concentrations in the diet but ADF was increased and its lower digestibility affected OM and DM digestibility. Starch digestibility decreased greatly after NDF levels peaked at approximately 35 to $36 \%$ regardless of $\mathrm{F}$ :C of the diet, suggesting that because the digesta passage rate is increased as CST increases in a controlled feeding scenario, valuable dietary starch might be lost due to low fermentation once past the rumen. In the same manner, $\mathrm{N}$ and microbial protein synthesis were enhanced as CST was added to an $\mathrm{HC}$ control-fed scenario, whereas the opposite happened in LC-fed heifers, being maximized in both type of diets at 35 to $36 \%$ NDF. Emissions of $\mathrm{NH}_{3}-\mathrm{N}$ from slurries of manure were not affected by $\mathrm{F}: \mathrm{C}$ treatments but interacted in a consistent manner as N retention in HC- and LC-fed heifers. Total manure was not different between $\mathrm{HC}$ or LC diets, but a shift occurred from water being excreted in urine toward water excreted in feces as dietary fiber linearly increased in the diets. Finally, inclusion of fiber through the use of CST plays an important role and interacts with concentrate levels in the diet when fed precisely to meet dairy heifers' requirements.

\section{ACKNOWLEDGMENTS}

Appreciation is extended to M. Long for laboratory assistance, G. I. Zanton for assistance with animals and data collection, A. N. Hristov for valuable comments, and C. Jones for editorial assistance (all of Penn State Dairy and Animal Science Department).

\section{REFERENCES}

AOAC. 1990. Official Methods of Analysis. 15th ed. Assoc. Off. Anal. Chem., Arlington, VA.

Bannink, A., H. Valk, and A. M. Van Vuuren. 1999. Intake and excretion of sodium, potassium, and nitrogen and the effects on urine production by lactating dairy cows. J. Dairy Sci. 82:1008-1018.

Beckman, J. L., and W. P. Weiss. 2005. Nutrient digestibility of diets with different fiber to starch ratios when fed to lactating dairy cows. J. Dairy Sci. 88:1015-1023.

Brown, M. S., C. H. Ponce, and R. Pulikanti. 2006. Adaptation of beef cattle to high-concentrate diets: Performance and ruminal metabolism. J. Anim. Sci. 84(E-Suppl.):E25-E33.

Burkholder, K. M., A. D. Guyton, J. M. McKinney, and K. F. Knowlton. 2004. The effect of steam flaked or dry ground corn and supplemental phytic acid on nitrogen partitioning in lactating cows and ammonia emission from manure. J. Dairy Sci. 87:2546-2553.

Burkitt, D. P. 1973. Epidemiology of large bowel disease: The role of fibre. Proc. Nutr. Soc. 32:145-149.

Chen, X. B. 1989. Excretion of purine derivatives by sheep and cattle and its use for the estimation of absorbed microbial protein. $\mathrm{PhD}$ Diss. University of Aberdeen, UK.

Chen, X. B., and M. J. Gomes. 1992. Estimation of microbial protein supply to sheep and cattle based on urinary excretion of purine derivatives: An overview of technical details. Rowett Research Institute, Aberdeen, UK.

Cole, N. A., R. R. Johnson, and F. N. Owens. 1976. Influence of roughage level on site and extent of digestion of whole shelled corn by beef steers. J. Anim. Sci. 43:483-489.

Colucci, P. E., G. K. MacLeod, W. L. Grovum, L. W. Cahill, and I. McMillan. 1989. Comparative digestion in sheep and cattle fed different forage to concentrate ratios at high and low intakes. J. Dairy Sci. 72:1774-1785.

Colucci, P. E., G. K. MacLeod, W. L. Grovum, I. McMillan, and D. J. Barney. 1990. Digesta kinetics in sheep and cattle fed diets with different forage to concentrate ratios at high and low intakes. J. Dairy Sci. 73:2143-2156.

Eastridge, M. L., B. L. Bucci, and C. V. D. M. Ribeiro. 2009. Feeding equivalent concentrations of forage neutral detergent fiber from alfalfa hay, grass hay, wheat straw, and whole cotton seed in corn silage diets to lactating cows. Anim. Feed Sci. Technol. 150:86-94.

Eng, K. S., J. C. Smith, J. H. Craig, and M. E. Riewe. 1964. Rate of passage of concentrate and roughage through digestive tract of sheep. J. Anim. Sci. 23:1129-1132.

Firkins, J. L., M. L. Eastridge, N. R. St-Pierre, and S. M. Noftsger. 2001. Effects of grain variability and processing on starch utilization by lactating dairy cattle. J. Anim. Sci. 79:E218-E238.

Galyean, M. L., and P. J. Defoor. 2003. Effects of roughage source and level on intake by feedlot cattle. J. Anim. Sci. 81:E8-E16.

Halevi, A., H. Neumark, and S. Amir. 1973. Straw in different proportions as sole roughage in diets for cows in mid-lactation. J. Dairy Sci. 56:1424-1428.

Hall, M. B., A. N. Pell, and L. E. Chase. 1998. Characteristics of neutral detergent soluble fiber fermentation by mixed ruminal microbes. Anim. Feed Sci. Technol. 70:23-39. 
Heinrichs, A. J., R. E. Kiernan, R. E. Graves, and L. J. Hutchinson. 1987. Survey of calf and heifer management practices in Pennsylvania dairy herds. J. Dairy Sci. 70:896-904.

Hill, S. R., K. F. Knowlton, R. E. James, R. E. Pearson, G. L. Bethard, and K. J. Pence. 2007. Nitrogen and phosphorus retention and excretion in late-gestation dairy heifers. J. Dairy Sci. 90:5634-5642.

Hoover, W. H., and S. R. Stokes. 1991. Balancing carbohydrates and proteins for optimum rumen microbial yield. J. Dairy Sci. 74:3630-3644.

Hungate, R. E. 1966. The Rumen and its Microbes. Academic Press, New York, NY.

Huntington, G. B., and P. J. Reynolds. 1983. Net volatile fatty acid absorption in nonlactating Holstein cows. J. Dairy Sci. 66:86-92.

James, T., D. Meyer, E. Esparza, E. J. DePeters, and H. Perez-Monti. 1999. Effects of dietary nitrogen manipulation on ammonia volatilization from manure of Holstein heifers. J. Dairy Sci. 82:24302439 .

Keys, J. E., and W. Smith. 1981. Effects of dried poultry excreta on growth, intake, and digestion of corn stover silage diets by yearling dairy heifers. J. Dairy Sci. 64:211-216.

Lascano, G. J., and A. J. Heinrichs. 2009. Rumen fermentation pattern of dairy heifers fed restricted amounts of low, medium, and high concentrate diets without and with yeast culture. Livest. Sci. 124:48-57.

Lascano, G. J., G. I. Zanton, and A. J. Heinrichs. 2009a. Concentrate levels and Saccharomyces cerevisiae affect rumen fluid-associated bacteria numbers in dairy heifers. Livest. Sci. 126:189-194.

Lascano, G. J., G. I. Zanton, A. J. Heinrichs, and W. P. Weiss. 2010. Technical note: A noninvasive urine collection device for female cattle: Modification of the urine cup collection method. J. Dairy Sci. 93:2691-2694

Lascano, G. J., G. I. Zanton, M. L. Moody, P. A. Topper, E. F. Wheeler, and A. J. Heinrichs. 2008. Short communication: Effect of changing the ratio of forage to concentrate on ammonia emissions by dairy heifers. J. Dairy Sci. 91:4301-4306.

Lascano, G. J., G. I. Zanton, F. X. Suarez-Mena, and A. J. Heinrichs. 2009b. Effect of limit feeding high- and low-concentrate diets with Saccharomyces cerevisiae on digestibility and on dairy heifer growth and first-lactation performance. J. Dairy Sci. 92:51005110 .

Littell, R. C., P. R. Henry, and C. B. Ammerman. 1998. Statistical analysis of repeated measures data using SAS procedures. J. Anim. Sci. 76:1216-1231.

Misselbrook, T. H., J. M. Powell, G. A. Broderick, and J. H. Grabber. 2005. Dietary manipulation in dairy cattle: Laboratory experiments to assess the influence on ammonia emissions. J. Dairy Sci. 88:1765-1777.

Moody, M. L., G. I. Zanton, J. M. Daubert, and A. J. Heinrichs. 2007. Nutrient utilization of differing forage to concentrate ratios by growing Holstein heifers. J. Dairy Sci. 90:5580-5586.

Murphy, T. A., F. L. Fluharty, and S. C. Loerch. 1994. The influence of intake level and corn processing on digestibility and rumi- nal metabolism in steers fed all-concentrate diets. J. Anim. Sci. $72: 1608-1615$.

Nordin, M., and R. C. Campling. 1976. Effect of the amount and form of roughage in the diet on digestibility of whole maize grain in cows and steers. J. Agric. Sci. 87:213-219.

NRC. 2001. National Research Council. The Nutrient Requirements of Dairy Cattle. 7th rev. ed. Nat. Acad. Press, Washington, DC.

Owens, F. N., and H. R. Isaacson. 1977. Ruminal microbial yields: Factors influencing synthesis and bypass. Fed. Proc. 36:198-2202.

Pina, D. S., S. C. Valadares, L. O. Tedeschi, A. M. Barbosa, and R. F. D. Valadares. 2009. Influence of different levels of concentrate and ruminally undegraded protein on digestive variables in beef heifers. J. Anim. Sci. 87:1058-1067.

Polan, C. E. 1988. Update: Dietary protein and microbial protein contribution. J. Nutr. 118:242-248.

Reynolds, C. K., H. F. Tyrrell, and P. J. Reynolds. 1991. Effects of diet forage-to-concentrate ratio and intake on energy-metabolism in growing beef heifers - Whole-body energy and nitrogen balance and visceral heat-production. J. Nutr. 121:994-1003.

Sarwar, M. J. L. Firkins, and M. L. Eastridge. 1991. Effect of replacing neutral detergent fiber of forage with soyhulls and corn gluten feed for dairy heifers. J. Dairy Sci. 74:1006-1017.

Schmidt-Nielson, K. 1984. Scaling: Why is Animal Size so Important? Cambridge University Press, New York, NY.

Stern, M. D., and W. H. Hoover. 1979. Methods for determining and factors affecting rumen microbial protein synthesis: A review. J. Anim. Sci. 49:1590-1603.

Valadares, R. F., G. A. Broderick, S. C. Valadares Filho, and M. K. Clayton. 1999. Effect of replacing alfalfa silage with high moisture corn on ruminal protein synthesis estimated from excretion of total purine derivatives. J. Dairy Sci. 82:2686-2696.

Van Soest, P. J. 1994. Nutritional Ecology of the Ruminant. 2nd ed. Comstock Publishing, Ithaca, NY.

Van Soest, P. J., J. B. Robertson, and B. A. Lewis. 1991. Methods for dietary fiber, neutral detergent fiber, and nonstarch polysaccharides in relation to animal nutrition. J. Dairy Sci. 74:3583-3597.

Wylie, M. J., T. W. White, W. C. Ellis, and J. H. Matis. 1990. The flow of undigested corn residues through the gastrointestinal-tract of cattle. J. Anim. Sci. 68:3843-3852.

Zanton, G. I., and A. J. Heinrichs. 2008. Rumen digestion and nutritional efficiency of dairy heifers limit-fed a high forage ration to four levels of dry matter intake. J. Dairy Sci. 91:3579-3588.

Zanton, G. I., and A. J. Heinrichs. 2009. Digestion and nitrogen utilization in dairy heifers limit-fed a low or high forage ration at four levels of nitrogen intake. J. Dairy Sci. 92:2078-2094.

Zanton, G. I., and A. J. Heinrichs. 2010. Short communication: Analysis of milk yield and composition for dairy heifers limit-fed lower forage diets during the rearing period. J. Dairy Sci. 93:4730-4734.

Zebeli, Q., M. Tafaj, H. Steingass, B. Metzler, and W. Drochner. 2006. Effects of physically effective fiber on digestive processes and milk fat content in early lactating dairy cows fed total mixed rations. J. Dairy Sci. 89:651-668. 